\title{
The Relationship between University Students' Training in Computing and their Motivation to Utilize ICT Resources in Learning in Selected Universities in Nakuru County, Kenya
}

\author{
Kageni Njagi \\ Department of Education, Kabarak University, Kenya \\ Bernard Chemwei \\ Department of Education, Kabarak University, Kenya \\ Leo B. Ogoala \\ Faculty of Education and Community Studies, Egerton University
}

\begin{abstract}
Over the past few years, the use of information and communication technologies (ICT) in education has grown rapidly. The benefits of ICT adoption are evident. However, it is a known fact that teachers face many challengesin integrating ICTs in their teaching to enhance student learning. Based on a study of selected universities in Kenya, this paper examines the relationship between university students' training in computing and their motivation to use ICT resources to learn. The study was guided by Rogers Diffusion of Innovations theory of 2003 which addresses change levels that teachers progress through in technology integration. Purposive sampling technique was used to select five universities that offer Bachelor of Education degree and 404 respondents who participated in the study. Data was collected using a questionnaire. The data collected was analysed descriptively with the help of the SPSS computer program version 20.0 and presented in the form of frequencies, means, standard deviation and percentages. The inferential statistics used to determine relationships among variables was the Pearson Moment Correlation. A p-value of less than 0.05 was interpreted as significant. The results of the study indicated that there was a significant relationship between university students' level of training and their motivation to use ICT resources for learning. Based on the findings, it is recommended that ICT integration be made part of undergraduate training in universities in order to equip future educators with ICT skills and that higher education institutions should provide in-service training on ICTs for teachers. The study contributes vital knowledge on the challenges of integration of ICT in institutions of higher education in Kenya. This will help policy makers to come up with strategies to ensure ICT is integrated in learning institutions to enhance learning outcomes and improve the quality of education.
\end{abstract}

Keywords: Bachelor, Education, Computing, Kenya, Teacher Training, Motivation, Integration, Universities, ICT

\section{INTRODUCTION}

In recent years, teacher education has gained a lot of prominence in the Kenyan education system (Abenga, 2005). This takes cognizance of the fact that no education system can rise above the quality of its teachers. Training is important in preparing teachers for their work since it equips them with necessary knowledge, skills and attitudes needed to enable them perform their duties competently. This importance is further reiterated in the goals of teacher training as enunciated in the national policy on education. Broadly speaking, teacher education seeks to contribute towards the following objectives: improvement of the general educational 
background of trainee teachers; increase the knowledge base and broad understanding of the subject matter of the trainee teachers; increase of the pedagogy skills; provide a deeper understanding of the pupils; improve on instructional skills, and thus contribute to better and effective learning. Teacher training also seeks to contribute towards the development of practical skills and competencies of the trainees.

The training of secondary school teachers in Kenya is undertaken at teacher training colleges and at Universities. Graduate teachers are trained in the Faculties of Education in nearly all public and in some private universities. Teacher training programmes are available at preservice, in-service and professional development of teachers at all the levels.

Currently, Kenya has 48 public and private universities. Usually, students who attain grade 'C' in their Kenya Certificate of Secondary Education examination qualify to be admitted to train as teachers. All these categories receive a pre-service training of four years. Because teachers are the key agents in educational change, continued calls to raise the standards of student learning and achievement have now focused on national policies on the quality of teachers and their teaching in classroom (Day, 1999). The government has demonstrated commitment to raise the level of secondary school teacher education to international standards. The efforts include equipping the institutions with ICT equipment.

In many universities that train teachers, trainees are expected to study two academic subjects which they will be expected to teach in secondary schools upon completion of their course. The same case applies to those admitted into the three-year diploma programmes in teacher training colleges. University-based teacher training is more flexible owing to their autonomy in deciding on the admission criteria, teacher education curriculum and assessment procedures. Undergraduate teacher education programmes take four years. The duration of teacher education influences the supervision of student-teachers during practicum, curriculum to be covered, and the training process (Avalos, 1991).

Among other concerns, Abenga (2005) points out that the teaching methods used in teacher training represent an important factor in teachers' education and in every other education. Abenga (ibid.) recommends that lectures delivered to passive students have to make way for the many forms of active teaching such as the use of ICTs. Therefore, teacher-training institutions ought to be equipped with the necessary teaching and learning materials and aids. Better still those institutions should be equipped with the most modern and up-to-date resources such as computers. In addition, teachers need to be trained on the reliable methods of teaching. These methods should effectively connect training programmes with performance of teachers. The trainers' educational technology needs should be matched with the requirements of the training objectives and real work environment. Therefore, it is important that university-based teacher training programmes are restructured to ensure trainees have sufficient subject mastery and pedagogy (Ministry of Education [MOE], 2005).

\section{Trainee Teachers' Motivation to Utilise ICT Resources for Learning}

Motivation encompasses a multitude of factors driving the selection, the persistence and the engagement of particular activities to attain an objective. Motivation refers to the process whereby a goal-directed behaviour is instigated and sustained (Schunk, 1990). Motivational factors are, therefore, considered part of one's goal structures and beliefs about what is important. Sufficient motivation of trainee-teachers is closely related to the innovative role of 
technology. Some empirical researches have linked motivation to computer use by teachers (Marcinkiewicz, 1996; Sheingold \& Hadley, 1990).

According to Medlin (2001), most educators are motivated by the desire to achieve personal and professional goals in their careers. For example, educators employed by research institutions may have different career goals and work experiences than those employed to teach in universities. According to Braskamp and Ory (1994), assistant and associate professors have more publishing and tenure pressures while the full professors are concerned with consulting, advising and administrative duties. Work experiences include those in computer technology use in teaching, improvement of teaching and enhancing student learning.

Hertzberg (as cited in Chapman, 2003) theorises that hygiene and motivator factors increase an individual's motivation and satisfaction in his or her employment. Hygiene factors include basic work factors such as working conditions, job security, level of salary and benefits. Hertzberg (ibid.) maintains that if any of these basic work factors are absent, employees get dissatisfied and that certain motivational factors, such as self-actualisation, self-fulfilment and creative and challenging work, influence an employee's work performance and motivation. Recognition, responsibility and growth, which are connected to an individual's work environment, are also motivational factors. Hertzberg (ibid.) adds that an employee's true motivation comes from within, which suggests that both internal and external motivation factors are important in influencing an individuals' adoption of an innovation.

Medlin (2001) has identified the factors that motivate accounting faculty members in accredited North Carolina Schools of Business to adopt and use electronic technologies in their instruction. Medlin (ibid.) found significant differences in the following areas:

1. Social variables: friends, mentors, peer support, and students.

2. Organizational variables: mandate from the university and physical resource support.

3. Motivational variables: personal interest in instructional technology, personal interest in improvement in one's teaching, and personal interest in enhancing student learning.

\section{Statement of the Problem}

There are increasing calls from policy makers for educators, such as universities and colleges, in teacher education institutions to produce teachers who are skilled, confident and competent in using information and communication technologies for their personal and professional lives (Abenga, 2005; Gakuu, 2006; MOE, 2005). These calls are based on the increasing realization of the important role played by ICTs in enhancing teaching and learning. For this reason, teachereducators in teacher training institutions are required to model appropriate uses of ICTs in instruction to equip future teachers with the necessary knowledge, skills and attitudes to effectively use these skills in their working lives. In order to achieve the objectives of the Kenya Vision 2030, there is need to establish a computer supply programme that will equip students with modern ICT skills.

Despite some literature reporting the effectiveness of ICTs as instructional tools in teacher education, it is not clear whether teacher-educators are integrating them in the curriculum. There is no documented evidence to indicate the level of integration of these technologies in teaching, especially in higher education institutions in Kenya. Such evidence is necessary because without the knowledge and experience of ICT within the teaching fraternity, it would be impossible to impart this knowledge to the student. Furthermore, the integration of ICT in 
teacher education has been slow, which means there are critical factors that influence integration levels of ICT in teacher training colleges. One of the factors that influence trainee teachers' utilization of ICT resources is their training in computing skills (Abolade \& Yusuf, 2007; Redmann \& Kotrlik, 2004; Yidana, 2007). Since there seems to be a link between these factors and the level at which trainee teachers utilize ICT resources, this paper examines university students' training in computing and their motivation as some of the factors that influence the level of ICT use in teacher education.

\section{Limitations of the Study}

The research would have covered all the universities that train teachers in Kenya, both private and public, but because of time and cost constraints, a sample of six colleges out of the total 18 TTCs was used. A broader survey would have perhaps clarified the status of ICT integration in Kenyan teacher education institutions. As such, the findings of the study can only be applicable to teacher-educators in public primary teachers' colleges in Kenya.

\section{MATERIALS AND METHODS}

This study employed a descriptive survey design. Descriptive surveys help in determining the status of a defined population with respect to certain variables. They are flexible in tackling a range of problems related to attitudes, perspectives and beliefs of participants and can employ written questionnaires or interviews (McMillan, 2004).

The study was carried out in five Universities in Nakuru Kenya. Only those universities that offer Bachelor of Education degree were chosen. Furthermore, the universities made a good research population because the Government has shown commitment to improving teacher education to make it more relevant to the needs of the country in tandem with international trends (MOE, 2005). The selected universities that offer Bachelor of Education degrees are Egerton, Kenyatta, Laikipia, Kenya Methodist and Kabarak Universities. Higher education institutions were chosen because the government has been pushing for initiatives to integrate e-learning in all levels of education.

The target population for the study consisted of the Bachelor of Education students in the universities. All these universities have computer laboratories and are making efforts to improve their ICT capacity. The authors decided to use the simple random sampling technique since the population was within the reach of statistical evaluation. First, purposive sampling was used to select universities that offer Bachelor of Education Degrees. Thirty percent (30\%) of the total number of students was used. A total of 394 students responded to the questionnaire.

Researchers prefer using methods that provide high accuracy, generalisability and explanatory power, with low cost, rapid speed and maximum management and administrative convenience. Basing on this fact, a questionnaire was used in the study for complementary purposes. The data collected was analysed using the Statistical Package for Social Sciences (SPSS) version 20. Descriptive statistics, including frequencies, means, standard deviations, tables and percentages, were used for the data on the level of training on ICT. Percentages were also used to answer one question that asked the levels of students' training in the use ICTs for learning. Correlation was used to determine if a significant relationship existed between the level of training and their motivation to learn. The significance level was set at 0.05 . All statistical analyses were computed using the statistical packages for social sciences. 


\section{RESULTS AND DISCUSSION \\ University Students' Level of Training in ICT}

Most of the respondents $(\mathrm{N}=386)(95.8 \%)$ were computer literate while only $17(4.2 \%)$ were not. This indicates that most of the respondents have basic computer skills and can use software applications. These skills are useful in boosting the confidence of trainee-teachers and students to use computers for learning. Nevertheless, future training programmes should show teachers how to achieve specific educational objectives through the integration of ICT into teaching and learning, not just learning about computers.

\section{Students' Level of ICT Training}

An analysis of the results, as presented in Table 1, indicates that with regard to competence in ICT, $77.7 \%$ strongly agreedand $18.6 \%$ of the respondents agreed that they were competent in using word processors. Another $57.6 \%$ and $19.9 \%$ strongly agreed and agreed respectively that they were well trained in the use of spread sheets. Moreover, $49.1 \%$ were competent in data base management; 89.7 strongly agreed and agreed that they were good in using PowerPoint presentation programs; 82.9 strongly agreed and agreed that they use email, and 93.3\% strongly agreed and agreed that they use Internet in their daily learning.

Table 1: Trainee Teachers Level of ICT Training

\begin{tabular}{lllll}
\hline Level of training & \multicolumn{4}{l}{ Frequencies / Percentage } \\
\hline Computer Tool & SA & A & D & SD \\
\hline Word processing & $304(77.6)$ & $73(18.6)$ & $6(1.5)$ & $9(2.3)$ \\
Spread-sheets & $223(57.6)$ & $77(19.9)$ & $48(12.4)$ & $39(10.1)$ \\
Database management & $101(26.8)$ & $84(22.3)$ & $125(33.2)$ & $67(17.8)$ \\
Programming & $14(3.5)$ & $17(4.3)$ & $52(13.2)$ & $316(79.2)$ \\
Networking & $4(1.0)$ & $6(1.5)$ & $53(13.3)$ & $336(84.2)$ \\
PowerPoint & $190(49.7)$ & $153(40.1)$ & $18(4.7)$ & $21(5.5)$ \\
Web development & $7(1.7)$ & $13(3.2)$ & $79(20.2)$ & $292(74.7)$ \\
Interactive multimedia materials & $112(29.8)$ & $58(15.4)$ & $133(35.4)$ & $73(19.4)$ \\
E-learning & $94(23.7)$ & $8(2.0)$ & $49(12.3)$ & $246(62.0)$ \\
Internet & $289(75.5)$ & $68(17.8)$ & $11(2.9)$ & $15(3.9)$ \\
E-mail for communication & $278(68.8)$ & $53(14.1)$ & $26(6.9)$ & $19(5.1)$ \\
Computer maintenance & $4(1.0)$ & $12(3.1)$ & $67(17.1)$ & $306(78.8)$ \\
\hline
\end{tabular}

On the other hand, the least training on the use of computers for learning purposes are computer maintenance (1.0\% and strongly agreed and 3.1\% agreed), E-learning (27\% strongly agreed), web development (1.7\% strongly agreed and 3.2\%agreed), networking (1.0\%strongly agreed and $1.5 \%$ agreed) programming (3.5\% strongly agreed and $4.3 \%$ agreed).

It is apparent from the descriptive analysis in Table 2 that student-teachers had high levels of ICT training for such ordinary applications as word processing, spread sheets, data base management, internet, the use of E-mail for communication.However, they had low levels of ICT training use for more specialized applications such as networking, programming and computer maintenance. This means that student-teachers' knowledge in advanced computer skills is quite low.

This pattern of ICT integration validates Keengwe's (2007) findings; that the use of more mainstream and personal computer applications is common among faculty members and teachers. However, the level of ICT integration in general by teacher-educators remains very low. One probable reason for this is the fact that specialized applications increase the complexity of an innovation. This is also in line with Rogers' (2003) theory of diffusion of innovations which states that the complexity of an innovation is a hindrance to integration. In 
most cases, mainstream applications are believed to be compatible with the adopter's existing values.

\section{Influence of ICT Resources on Students Motivation to Learn}

Kurgat (2014) believes that the key motivating quality of ICT-mediated work is interactivity. This is because in many classrooms it can get a bit boring for students to just sit there listening to the teacher and looking at the chalkboard. Kurgat(ibid.) argues that students prefer an interactive program on the computer where they can click on parts of the body where it actually talks to them and they can see what it does, rather than just seeing a picture on the chalkboard.

Students see computer-based tools and resources as helping not just to effect tasks and improve presentation, but also to refine work and trial options. They associate the use of such tools and resources with changes in working ambience and classroom relations, as well as with raised interest and increased motivation on their part. Students welcome opportunities for independent working mediated by ICT in which they can engage more directly with appropriately challenging tasks; they are concerned that this reshaping of learning might be displacing valuable teaching.

Table 2 shows the influence of ICT resources on students' motivation to learn. Majority of the respondents contended that the use of ICT resources increased their frequency of attending classes $(M=3.05 \mathrm{SD}=1.17)$. It gave them an opportunity to research on the internet $(M=3.66$; $\mathrm{SD}=0.929)$. They also use ICT resources to submit assignments $(M=3.16 ; \mathrm{SD}=1.423)$. They further said they use ICT resources to receive results online $(M=3.10 ; S D=1.48)$; read notices, memos and other information online $(\mathrm{M}=3.03$; $\mathrm{SD}=1.328)$, andfor online communication with lecturer $(\mathrm{M}=2.80 ; \mathrm{SD}=1.322)$.

Table 2: Influence of ICT Resources on Students Motivation to Learn

\begin{tabular}{lrrr}
\hline & N & Mean & Std. Deviation \\
\hline Attending classes & 383 & 3.05 & 1.17 \\
Research on the internet & 382 & 3.66 & 0.929 \\
Submitting assignments online & 392 & 3.16 & 1.423 \\
Online communication with lecturer & 392 & 2.80 & 1.322 \\
& & & 1.480 \\
Receiving results online & 392 & 3.10 & 1.328 \\
$\begin{array}{l}\text { Reading notices, memos and other } \\
\text { information online }\end{array}$ & 392 & 3.03 & 1.12430 \\
& & & \\
Students motivation to learn mean & 394 & 3.0901 & \\
\hline
\end{tabular}

Generally, ICT can be a vehicle for engaging students' interest in subject topics, for example, through the interactive and multimodal qualities of computer-based work. Immediacy of access to resources and relevance of materials would render learning more enjoyable for students. Reduced handwriting requirements and higher quality presentation motivates students and increase students' self-esteem (Kurgat, 2014) 
Njagi, K., Chemwei, B., \& Ogola, L. B. (2015). The Realationship between Univesity Students' Training in Computin and their Motivation to Utilize ICT Resources in Learning in Selected Universities in Nakuru County, Kenya. Advances in Social Sciences Research Journal, 2(5) 74-82

\section{Relationship between Students' Training in Computing and their Motivation to Learn Hypothesis Test Results}

To test the hypothesis, data was collected using a questionnaire that contained seven items on students' motivation. As shown in Table 1, the results of the Pearson Moment Correlation Coefficient between the level of ICT training by students in Universities and their motivation to learn was $0.347^{* *}$. This was a positive relationship. Multiple regression analysis was then carried out to ascertain whether or not the relationship was significant. Therefore, there is a significant relationship between students' level of ICT training and their motivation to learn. Thus, the null hypothesis was rejected, implying that the teacher-educators' motivation influences their integration of ICT in teaching.

This state of affairs notwithstanding seems to agree with the views of Clifford, Friesen and Lock (2004) that traditional models of professional development like workshops and courses have not been particularly successful in helping learners find ways to integrate technology into their teaching and learning processes. In effect, faculty members and classroom teachers are not comfortable with their state of affairs. They often feel bad about not knowing how to use technology for teaching and learning.

These findings are consistent with those of Karsenti and Thibert (2006) who found that learner motivation is a key factor related to computer integration. It can, therefore, be deduced from the study that teachers who are motivated and have a strong commitment to foster learning processes integrate technology more easily in their teaching. With this in mind, the findings of the study show that ICT training and motivation are predictors of ICT integration in universities in Kenya.

Some studies have also shown that motivation heads the list of factors influencing teaching and learning in higher education. For instance, a study on the motivation of future teachers to integrate ICT into their teaching practices has shown that the presence of model instructors or participation in a course that optimises the use of ICT could have a positive impact on the motivation of future teachers to integrate ICT in their teaching practices (Karsenti \& Thibert, 2006). This means that future teachers taking practical education (practicum) in a setting that places importance on integration of ICT are more likely to have a special interest in integrating ICT in their own teaching practices. Besides, a future teacher with proficiency in ICT and wide experience integrating ICT during their college education will also be more inclined to integrate ICT into their teaching.

Trainee teachers who do not extensively integrate ICT into their teaching practices have few expectations of success integrating ICT, which often appears to be linked to their poor training and general computer literacy. These individuals also fail to see how ICT could enhance teaching and/or learning. Instead, they perceive ICT as a time-consuming exercise. They find school settings that make little use of ICT more reassuring than those that make extensive use of this technology. Hence, their very limited experience with integration of ICT during their university education is perceived as the reason teacher-educators do not integrate ICTs into their teaching.

In general, the findings indicated a generally positive motivation towards computers as tools. In particular, student-teachers were motivated by their competence to use ICT resources in their learning. Most of them occasionally upgraded their computing skills in order to maximize available computers. 
Furthermore, a majority of the respondents found ICT resources useful in class-related activities. Moreover, findings based on the hypothesis test indicated that there is a significant relationship between student teachers' training in computing and their motivation to use ICT resources in their learning. This, therefore, means that ICT competence is a significant predictor of student motivation to use ICT resources to learn. With this in mind, the findings of the study seem to suggest that universities should give greater consideration to student teachers' training in computing because it motivates them to use the ICT resources in learning.

\section{CONCLUSION AND RECOMMENDATIONS}

On the issue of student training on ICT, it was established that there is a significant correlation between university students' level of ICT training and their motivation to learn. This implies that the level of ICT training influences students' utilisation of ICT resources in their learning. It is therefore recommended that Bachelor of Education departments in universities should consider training their students well if ICT integration is to succeed. Since a strong, positive relationship exists between training in computing and motivation to learn, there is need to encourage, by means of incentives, students who exhibit positive motivation so as to improve the level of ICT integration. This can be done by introducing rewards such as the ICT Student of the Year Award.

\section{ACKNOWLEDGEMENT}

The authors of this article wish to acknowledge Kabarak University for funding the study that informed this paper.

\section{References}

Abenga, E. S. B. (2005). The adoption and use of new educational technologies in the training ofteachers of English in primary teachers' colleges in Kenya (Unpublished D.Phil thesis).Moi University, Eldoret.

Abolade, A. O., \& Yusuf, M. O. (2005).Information and communication technologies (ICTs) and the Nigerian teacher education.African Journal of Educational Studies, 3(1), 1-19.

Avalos, B. (1991). Approaches to teacher education: Initial teacher training. London: Commonwealth Secretariat.

Braskamp, L. A., \& Ory, J. C. (1994). Assessing faculty work. San Francisco: Jossey Bass.

Chapman, B. F. (2003). An assessment of business teacher-educators' adoption of computer technology (Unpublished doctoral dissertation). Blacksburg, Virginia: Virginia Polytechnic Institute and State University.

Clifford, P., Friesen, S., \& Lock, J. (2004).Coming to Teaching in the 21st Century: An Analysis of Innovative Teacher Preparation Practices for ICT Integration in Alberta. Research Report for Alberta Learning.

Day, C. (1999). Developing teachers: The challenges of lifelong learning. London: Falmer Press.

Gakuu, C. (2006). Factors that encourage e-learning among lectures in the University of Nairobi (Unpublished Ph.D Thesis).University of Nairobi, Nairobi.

Karsenti, T.,et Thibert, G. (2000). Comment former des enseignants motivants: des leçons à tirer de quatre études de cas. Dans Biennale de l'Éducation et de la Formation (pp. 233-234). Paris, France: APRIEF.

Keengwe, J. (2007). Faculty integration of technology into instruction and students' perception of computer technology to improve students' learning.Journal of Information Technology Education, 6, 169-180.

Kurgat, S. (2014).The Impact of Integrated E-Learning Approach on Business Studies SyllabusCoverage by Secondary Schools in Kenya. International Journal of Humanities and Social Science, 6(1), 165-174.

Marcinkiewicz, H. R. (1996). Motivation and teachers' computer use.Proceedings of the 18th National Convention of the Association for Educational Communication and Technology, pp. 467-472. ERIC Document, Reproduction No. ED397818.

McMillan, J. H. (2004). Educational research: Fundamentals for the consumer (4thed.). New York: Pearson. 
Njagi, K., Chemwei, B., \& Ogola, L. B. (2015). The Realationship between Univesity Students' Training in Computin and their Motivation to Utilize ICT Resources in Learning in Selected Universities in Nakuru County, Kenya. Advances in Social Sciences Research Journal, 2(5) 74-82

Medlin, B. D. (2001). The factors that may influence a member's decision to adopt electronic technologies in instruction (Doctoral dissertation).Virginia Polytechnic Institute and State University, Blacksburg.

Ministry of Education (MOE) (2005).Information and communication technology (ICTs) option paper.Retrieved from http://www.education.go.ke.

Redmann, D. H., \& Kotrlik, J. W. (2004). Analysis of technology integration in the teaching-learning process in selected career and technical education programmes. Journal of Vocational Education Research, 29(1).

Republic of Kenya (ROK) (2005b). Kenya education sector support programme 2005-2010. Delivering quality education and training to all Kenyans. Nairobi: Government Printers.

Rogers, D. (2003). A paradigm shift: technology integration for higher education in the New Millennium. AACE Journal, 1(13), 19-33.

Schunk, D. H. (1990).Goal setting and self-efficacy during self-regulated learning.Educational Psychologist, 25, 7186.

Sheingold, K., \& Hadley, M. (1990).Accomplished teachers: Integrating computers into classroom practice. New York: Centre for Technology in Education, Bank Street College of Education.

Yidana, I. (2007). Faculty perceptions of technology integration in the teacher education curriculum: a survey of two Ghanaian universities (Unpublished doctoral dissertation). University of Ohio, Ohio. 